\title{
Women combatants in West Africa, recruitments and dimensions: a theoretical analysis
}

\author{
Adebowale Adeyemi-Suenu \\ Department of History and International Studies, Faculty of Arts, Lagos State University, \\ Lagos, Nigeria \\ E-mail address: blackman_wale@usa.com
}

\begin{abstract}
Internecine wars in West Africa just like in other regions of Africa created unresolved problem which often throw up rebel groups and ethnic militias agitating for one form of demands or outright rejection of the existing social order. This situation often warranted illegal recruitments of childsoldiers, girl-soldiers, women combatants, and so on. This paper takes a theoretical look at the issues, problems, purposes, and dimensions of women combatants in West Africa. It therefore concludes that several condition create opportunities for the recruitments of women as combatants.
\end{abstract}

Keywords: wars in West Africa; child-soldiers; girl-soldiers; women combatants

\section{INTRODUCTION}

Post-Colonial states in West Africa have witnessed incessant outbreak of wars which came in different manifestations. The symptoms of collapse of civil order represents an aggravating trend that is anchored to the visceral ties of ethnicity, religion and agitations for resource control that transcend boundaries. While these accelerating concerns of domestic conflagration are not new in the post-colonial West African states, their outbreak in the 1990's has been characterised by the absence of legitimate sovereignty manifested in the nature of confrontations with the central government. This situation has led to the rise of novel warfare strategies such as child soldiers, girl soldiers, women combatants and the use of mercenaries. This work takes a look at the issues of women combatants in West Africa. It investigates the nature and methods of recruitments of women in West Africa with special focus on the Niger Delta of Nigeria. This work is divided into four parts. The first part is the introduction while the second part theoretically examined this concept and phenomenon within the realty of the unfolding and experienced realities in West Africa. The third aspect takes a look at its dimensions and the fourth part of this work contains the references. This work combines both historical and social science methods of investigations. This is necessary because of the nature of this work. 


\section{WOMEN COMBATANTS IN WEST AFRICA}

West African sub-region comprising states of recent colonial origin has been caught in a vortex of such traumatic social conflict which in a number of cases (Nigeria, Chad, Liberia, Sierra-Leone, Guinea Bissau) threatened to destroy the social fabric of the societies involved. Pressures arising from domestic pressures, combined with widespread irredentism, vigilantism and external intervention engendered a spiral of violence with incalculable consequences for the stability and development of these states in particular, and the sub-region in general. The Niger Delta of Nigeria presented an experimental case. The dimensions of violence occasioned by the causes of conflict enables the dimensions of the engaged strategies including the mode of recruitments and the soldiers of war. The focus, essence, dimensions, targets, demands and terrain enables the prevalence of women for objective strategic purposes which the objectives and strategies of the violence, on the parts of the rebels, demands. Women combatants are not new in the war memoirs of the history of wars in the pre-colonial African Empires and Kingdoms. The new dimensions and the nature of recruitments underscore its new novelty.

Contemporary discourse on women combatants places the issues on two major theoretical plains [1]. The first is legalistic which places the issue within the contest of international law and the rights of states to have its own army which may also include women [2]. This group of women passes through conventional and globally acceptable training routine and they are acceptable by the sovereign state as part of its soldier, trained, paid and mobilized to defend the country at all times.

This position raises political issues which may necessitates the extra-legal disposition which explains the recruitment of women by a rebel group or a group of people to unleash terror on a constituted authority or against a non-state group within a polity or across international boundaries [3]. This position raises two fundamental issues.

Firstly, women are recruited through means unknown to both domestic and international law and secondly an extra-legal recruitment connotes illegality and women recruited within this context are regarded as illegal women combatants.

Amplifying as this theoretical postulation appears, it fails to identify three other major issues. What were the possible endogenous conditions that may enable the recruitments and training of women outside normal or regular convention? Two, why would the recruitments of women be necessary in the process of violence against the constituted authority and thirdly, what impact would this irregular combatants have on the society when demobilised? However, this division on the basis of the above analysis becomes important because it identifies part of the conditions under which recruitments of women as combatants appear obtainable.

The above expository position seems to have a clear understanding in the position of Gauth and Green. They argued that

\footnotetext{
Although, there are acceptable rules and laws governing recruitments of soldiers. In a regular military formation, nothing like woman even when it exists in our consciousness. Mobilization and demobilization are regulated and controlled within the regulated and accepted rules [4].
}

Since the laid down rules are explicit relative to the recruitment of the armed forces of a nation, that of a rebel appears a contrast. Several reasons underscore recruitments and mobilization in an extra-legal recruitments pattern of irregular forces engaged by irregular armed forces. Buchana readily provided answer to this. To him, 


\begin{abstract}
...the primary objective for recruitment is to get willing accomplices who shares recruiting agents, bodies or networks or the identification of the realization of personal objectives within the vision(s) of the recruiting agents, bodies, networks etc. Several qualities and reasons are considered before recruitment [5].
\end{abstract}

The reasons and qualities of those to be recruited were not outlined by Buchana but however, it is vivid that the recruitment never followed the conventional methods of recruitments but the soldiers of war in an irregular formation consists of girls, boys, women and men.

This distinction in terms of age and gender explains the disrespect for rules and the degree of illegalities in the recruitments exercise perpetrated by the extra-legal bodies who engages the services of the women combatants and other categories of soldiers for the prosecution of wars and realisation of objectives. This is a common phenomenon in the contemporary wars in West Africa. Wars fought for reasons ranging from border disputes [6], civil wars [7], and environmental problems [8] etc. The use of women as combatants has not received much intellectual attention from scholars [9]. However, the main concern has repeatedly been on the transformation in a post crisis social environment.

While United Nations and concerned Rights organisation [10] have been really concerned with the use of a girl or soldier in the wars especially in the third world environment, similar concern of equal magnitude have not been extended to the conditions of women lured, conscripted or voluntarily, for reasons, offered to be a combatant in war she is directly affected or as mercenary. Who then is this woman combatant? We shall later return to this issue which raises serious conceptual positions.

The mode, method and reasons for joining the groups or those with alternative political agenda but seeks rebellion or armed alternative as the method for pursuing their agenda. Bishop Hellenski [11] was of the opinion that,

...aside the reasons for rebellion, generally advanced, against a constituted authority, there are collective and individual reasons why the groups came together to pursue a defined agenda.

\title{
3. COMBATANTS
}

Literarily, combatants connote the idea of persons involved in fighting in a war. It may, in a strategic language, be referred to as a group of trained, mobilized men for the purpose of achieving a country's national objectives [12]. Mbu got this view rather clearly when says that

Nigerian soldiers are in combats at different social climes outside

Africa. They are trained, catered for and mobilized for certain objectives for the preservation of humanity and its environment [13].

This position only amplifies official and legally acceptable model of recruitments into the armed forces of a nation in which the same is mobilised for official usage. It leaves out the recruitments of combatants within the context under discussion. However, Mbu's articulation suffices as a definition even if it fails to capture the extra-legal recruitments method in an irregular order. A combatant, under any social condition, would then mean those recruited, directed and employed in a war, crisis, and matinee etc situation for the employment of the objectives of the group or groups who mobilizes same towards a particular direction which 
often, is towards certain objectives. This broader understanding was advanced on one hand and it also underscored the relevance of Ayoob [14] and Tairu's [15] prognosis.

Combatants, in the context of the Niger Delta militants' experience, connote an extra legal and irregular method which rebelled groups have employed elsewhere in Africa. Underscoring this methods of recruitments, has been the nature, circumstances and the availability of the willing and ready to be mobilized untrained, ill-trained, semi-trained, illdemobilized regular soldiers and those aggrieved individuals who voluntarily joined for ethnic primordial sentiments and other anti-nation disposition [16]. The last group have largely refused to get disarmed because they have largely lost confidence in Nigerian project [17]. Bubaraji gladly explained how he voluntarily joined the Asari Dokubo's group because of the need to defend his father's homeland - the Niger Delta. This position reinforces another view elsewhere.

Bubaraji Emile was also a former combatant interviewed on $23^{\text {rd }}$ Sept., 2013. James angrily explained why it has been easy to get men, women and children to unleash terror in Nigeria [18]. To him,

\begin{abstract}
...the neo-colonial Nigerian state has failed in its responsibility as an impartial umpire in the regulation of differences among the various ethnic nationalities on one hand; it has also betrayed the citizens in the provision of common goods. Thus, ready soldiers are available to kill and bury this sorrowful edifice"
\end{abstract}

The above scenario painted by James partly explains the condition for the availability of willing combatants in a neo-colonial environment like Nigeria. The seeming frustrations of rising expectations although play a part but a willing combatant may also be a trigger-happy personality who probably for various reasons missed the opportunity of being enlisted as a regular soldier in regular armed forces of a country. Having being ruled by his heart and also un-occupied becomes available as a combatant in this circumstance [19].

Rexlong [20] sees a combatant as a man who is engaged in a lawful war as dictated by his country. This is also an official definition which fails to capture the reality of forceful enlistment as combatants or irregular disposition to be used or counted, for various reasons, as combatants in war or rebellion against sovereign authority.

\title{
4. GIRL COMBATANTS
}

The idea of girl combatants connotes the idea of a child soldier. This directly refers to the idea of children as combatants. The outbreak of armed insurgencies in Liberia and SierraLeone in 1989 and 1991 respectively, not only earned West Africa the unenviable tag of the most volatile sub-region in the 1990's but equally generated thousands of child soldiers and significant percentage of girls. This situation attracted other environments and armed wielding groups to readily enlist girls as combatants. The Niger Delta environment is not excluded. This girls became cannibals and they are now associated with horrendous and highly unusual atrocities which contributes to the nature and dimensions of the security problems in the Niger Delta.

The recruitment of girls took two forms. Forced and voluntary [21].

A girl is a female child; a young woman who is not married. This understanding creates the problems age delineation. In this wise, a girl could be a female gender up to 16-18 years. 
In this wise, a girl is a child treated as women combatants in an irregular armed formation or by rebels or militant groups. This is particularly common in Niger Delta.

\section{FEMALE COMBATANTS}

Owens and Gladys [22] have tried to explain away the theoretical exigency of looking at the issue of female combatants as against the common separation into categories for the reason of clarity. These scholars were of the opinion that a girl is a female as well as a woman. In this wise, it is more convenient to talk about female combatants or soldiers than the normal categorizations which scholars often address. While this appears correct relative to gender, it is necessary to categorize for official policy reasons and also for lucid intellectual necessities which may attract categorizations for groups' identification.

\section{WOMEN COMBATANTS}

Women combatants are female soldiers recruited by rebels, militants or in a regular armed forces of a country to fight for certain objectives. In the context of this work, women combatants refers to all categories of females gender recruited for combats and deployed for same by the Niger Delta warlords. This distinction is necessary because it is difficult to see any female combatants in the rank and file of the Niger Delta militants whose age is less than sixteen years (16 years) [23]. This would also enable us to deeply appreciate the nature and degree of the effects of the women combatants on the post crisis/war Niger Delta.

\section{CONCLUSION}

Women combatants are a common phenomenon in strategic/military discourse in West Africa. Although, this issue manifests in other regions of Africa but its prevalence in the West Africa sub region cannot be de-emphasized. While it is theoretically difficult to categorise who a woman combatant is, but the issue of age differences help in resolving this theoretical problem. Several conditions predisposed women for recruitments. Some of these problems are beyond the control of women but few are their personal resolve occasioned by the problems of insecurity and economic backwardness. Women combatants are illegally recruited by ethnic militias or the rebel groups and the forms of recruitment betray all known conventions.

\section{References}

[1] Richard G. (1970). War Agents in Africa. Roycrest Inc., New York. Pp. 77.

[2] Gabriel R. (2002). Wars in West Africa. Panaf Press, London. Pp. 35.

[3] Bonnah J. (2011). Non-State Actors In West Africa. Westron Inc., New York. Pp. 107.

[4] Buchana H. (2008). The Armed Forces: Rules and Order. Penguin Bks, London. Pp. 72.

[5] Ibid., pp. 172.

[6] Johan I (2006). Border Disputes in Africa. Willcloff, New York. Pp. 93. 
[7] Richard R. (2005). Liberia: The Civil War. Panthar, Abuja, Nigeria.

[8] Abudu Y. (2009). Shell in the Niger Delta. Penthrust Ltd. Enugu, Nigeria pp. 12.

[9] Aruya R. (2010). Instruments of Wars in Africa. RichView Inc., Ethiopia, pp. 142.

[10] Kingsley H. (2008). Conscripted Women in the Niger Delta. The Publication of Environmental Rights Agenda (ERA), Nigeria. Vol.3, Nos 2. Pp. 21.

[11] Hellenski B. ( 2002 ). The Rebels in Africa. Williams, New York. Pp. 71.

[12] Richard H. (1997). Combatants at War. Henkins Press, New York. Pp. 56.

[13] Mbu A. (2007). Nigerian Soldiers. Heinemann, Nigeria. Pp. 29.

[14] Ayoob A. (2009). Civil Wars in Africa. Maineth Inc., Ethiopia. Pp. 76.

[15] Tairu B. (2011). Genocide in Africa. Panaf Press. Lagos. Pp. 117.

[16] Gladys Wike was a woman combatant who has no confidence in Nigeria's project. She was interviewed in Port-Harcourt on $23^{\text {rd }}$ Sept., 2013.

[17] James R. (2002). Nigeria: A failed Neo-Colonial Edifice. Boltof Press, Lagos, Nigeria, pp. 118.

[18] Lizzy Inokoba is a woman combatant interviewed on the $17^{\text {th }}$ Sept., 2013.

[19] Ada Ibori explains how she loves pulling guns. Was interviewed $17^{\text {th }}$ Sept., 2013.

[20] Rexlong B. (1999). The Regiments. Ivor Press, Havanna. Pp. 62.

[21] Williams H. (2003). Girl Soldiers in West Africa. Golstone Inc., New York. Pp. 113.

[22] Owens B., Gladys H. (2007). Female Soldiers in Africa. Pultarch, Norway, pp. 23.

[23] Asari Dokuba was interviewed in Portharcourt at the premises of the Centre for Advance Social Sciences on 14 September, 2013. 